УДК 547.913

\title{
TЕРПЕНОИДЫ И ДРУГИЕ КОМПОНЕНТЫ ARTEMISIA SOGDIANA И A. SEROTINA, ПРОИЗРАСТАЮЩИХ В УЗБЕКИСТАНЕ
}

\author{
() Р.Ф. Мухаматханова", Х.М. Бобакулов, И.Д. Шамьянов, Н.Д. Абдуллаев
}

Институт химии растительных веществ им. акад. С.Ю. Юнусова АН РУз, ул. Мирзо Улугбека, 77, Ташкент,100170 (Узбекистан), e-mail: rfm8@yandex.ru

\begin{abstract}
Проведено исследование вторичных метаболитов методом хромато-масс-спектрального анализа бензольных экстрактов надземных частей полыни согдийской Artemisia sogdiana Bunge. и полыни поздней Artemisia serotina Bunge., собранных в период бутонизации в отрогах Нуратинского хребта Джизакской области Узбекистана.

Основными компонентами A. sogdiana являются 5,5-диметил-2(5Н)-фуранон - 17,99\%, $\gamma$-винил- $\gamma$-валеролактон $-8,71 \%$; монотерпеноиды: 1,8 -цинеол - 28,13\%, $\alpha$-туйон - 3,18\%, $\beta$-туйон - 2,69\%, камфора - 8,65\%, филифолид А$4,05 \%$, хризантенон $-5,23 \%$.

Основными компонентами $A$. serotina являются 1,8 -цинеол - 10,08\%, филифолид А $-8,62 \%$, хризантенон 13,00\%., (Z)-жасмон - 1,95\%.

Представленные в данном сообщении A. sogdiana и A. serotina оба имеют в наличии $\alpha$-пинен, 5,5 -диметил-2(5H)фуранон, $\gamma$-винил- $\gamma$-валеролактон, 1,8-цинеол, хризантенон, $\alpha$-изофорон и филифолид А, которые могут стать маркерными соединениями для них.

Необходимо также отметить, что обнаруженные летучие монотерпеноиды $\alpha$ - и $\beta$-туйоны, камфора и 1,8 -цинеол являются активными ингибиторами прорастания семян и роста проростков окружающих однолетних растений.

В результате проведенных исследований методом хромато-масс-спектрального анализа бензольных экстрактов надземных частей $A$. sogdiana и A. serotina впервые идентифицировано 19 и 22 соединения соответственно.

Ключевые слова: Artemisia sogdiana Bunge., полынь согдийская, Artemisia serotina Bunge., полынь поздняя, терпеноиды, вторичные метаболиты, хромато-масс-спектральный анализ.
\end{abstract}

\section{Введение}

Род Artemisia L. - один из крупнейших родов в семействе Asteraceae, представлен в Узбекистане 81 видами, которые по морфологическим признакам разделены на три подрода: Artemisia L, Dracunculus (Bess) и Seriphidium (Bess) Rouy.

Высокая степень устойчивости к ксеротермическим факторам и нетребовательность в отношении почв позволяет им произрастать в аридных и полуаридных зонах Узбекистана, где они являются основными эдификаторами, особенно полыни подрода Seriphidium (Bess) Rouy, и тем самым составляют основу кормовых ресурсов отгонного животноводства в зимний период. Полыни первыми заселяются на песках, являясь пескоукрепителями, дают возможность в дальнейшем поселяться другим растениям. Их площадь произрастания в пустынных и полупустынных зонах Республики составляет более 24 млн га. [1].

Мухаматханова Римма Фаильевна - старший научный сотрудник-исследователь лаборатории химии кумаринов и терпеноидов, e-mail: rfm8@yandex.ru Бобакулов Хайрулла Мамадиевич - старший научный сотрудник лаборатории физических методов исследований, e-mail: khayrulla@rambler.ru Шамьянов Ильдар Джамильевич - старший научный сотрудник лаборатории химии кумаринов и терпеноидов, e-mail: sh-v@rambler.ru

Абдуллаев Насрулла Джалилович - ведущий научный сотрудник лаборатории физических методов исследований, e-mail: n_abdullaev@rambler.ru
Artemisia sogdiana Bunge - полукустарник высотой 40 см с 10-15-сантиметровой древесной многолетней частью. Широко распространенный вид полыни в Узбекистане. Произрастает в Ферганской долине, в предгорьях Кураминского, Алайского, Туркестанского, Нуратинского, Зеравшанского, Гиссарского хребтов [2, 3].

В литературе не обнаружено сведений об исследовании летучих компонентов Artemisia sogdiana Bunge.

\footnotetext{
* Автор, с которым следует вести переписку.
} 
Artemisia serotina Bunge - полукустарник высотой 40-80 см, является эндемиком Средней Азии. Это растение произрастает на различных типах почв, иногда на слабо засоленных местах в равнине, предгорьях и реже в нижнем поясе гор. Распространен по всему Узбекистану [2, 3].

Согласно литературным данным, летучие соединения данного вида полыни практически не изучены. Только показано, что эфирное масло, выделенное из Artemisia serotina, произрастающей в Казахстане, продуцирует пять монотерпеноидов (туйон, карвон, камфора, 1,8-цинеол, неотуйиловый спирт) [4, 5].

Популяция Artemisia serotina, произрастающая в Узбекистане, ранее не исследовалась.

В данном сообщении приводятся результаты исследования летучих соединений двух видов полыней: Artemisia sogdiana и A. serotina, относящихся к подроду Seriphidium (Bess) Rouy.

\section{Экспериментальная часть}

Для проведения исследований эти виды полыней были собраны в период бутонизации и начала цветения в Джизакской области Узбекистана в отрогах Нуратинского хребта. Видовая принадлежность Artemisia sogdiana и A. serotina определена канд. биол. наук Н.Ю. Бешко - сотрудником Института генофонда растительного и животного мира АН РУз путем сопоставления собранных гербарных образцов с гербарными материалами, хранящимися в Центральном гербарии Узбекистана (объединенные гербарии Ташкентского государственного университета и Института ботаники АН РУз).

Экстракция Artemisia sogdiana и A. serotina проведена по следующей методике: каждый вид растения (1 г) экстрагировали бензолом в соотношении $1: 6$ (вес- объем). Сгущенный экстракт анализировали методом хромато-масс-спектрального анализа.

Экстракты анализировали на газовом хроматографе Agilent 7890A GC с квадрупольным массспектрометром Agilent 5975C inert MSD в качестве детектора. Разделение компонентов смеси проводили на кварцевой капиллярной колонке $\mathrm{HP}-5 \mathrm{MS}(30 \mathrm{~m} \times 250 \mu \mathrm{m} \times 0,25 \mu \mathrm{m})$ в температурном режиме: $50{ }^{\circ} \mathrm{C}$ $(0$ мин $)-4{ }^{\circ} \mathrm{C} /$ мин до $200{ }^{\circ} \mathrm{C}(2$ мин $)-10{ }^{\circ} \mathrm{C} /$ мин до $290{ }^{\circ} \mathrm{C}(10$ мин). Объем вносимой пробы $1 \mu$ (гексан, бензол), скорость потока подвижной фазы (Не) 1,3 мл/мин. Компоненты идентифицировали на основании сравнения характеристик масс-спектров с данными электронных библиотек W8N05ST.L и NIST08 и сравнения индексов удерживания (RI) соединений определенного по отношению времени удерживания смеси $н$-алканов $\left(\mathrm{C}_{9}-\mathrm{C}_{20}\right)$.

\section{Обсуждение результатов}

Результаты хромато-масс-спектрального анализа приведены в таблицах 1 и 2.

Таблица 1. Летучие соединения бензольного экстракта надземной части A. sogdiana

\begin{tabular}{|c|c|c|c|}
\hline Название вещества & $\mathrm{R}_{\mathrm{t}}$, мин & Содержание, \% & RI \\
\hline Нонан & 4,72 & 0,58 & 902 \\
\hline$\alpha$-Пинен & 5,53 & 1,61 & 934 \\
\hline Камфен & 5,90 & 0,53 & 949 \\
\hline 5,5-Диметил-2(5Н)-фуранон & 6,03 & 17,99 & 954 \\
\hline$\beta$-Пинен & 6,63 & 1,14 & 978 \\
\hline$n$-Кумол & 8,01 & 0,99 & 1027 \\
\hline Эвкалиптол (1,8-цинеол) & 8,19 & 28,13 & 1033 \\
\hline$\gamma$-Винил- $\gamma$-валеролактон & 8,51 & 8,71 & 1043 \\
\hline ųис-Арбускулон & 8,86 & 1,91 & 1054 \\
\hline транс-Арбускулон & 9,46 & 1,34 & 1074 \\
\hline$\alpha$-Туйон & 10,55 & 3,18 & 1109 \\
\hline$\beta$-Туйон & 10,92 & 2,69 & 1120 \\
\hline$\alpha$-Изофорон & 11,06 & 1,05 & 1124 \\
\hline Хризантенон & 11,19 & 5,23 & 1128 \\
\hline Транс-Пинокарвеол & 11,64 & 1,50 & 1142 \\
\hline Камфора & 11,81 & 8,65 & 1147 \\
\hline Миртеналь & 13,57 & 0,79 & 1199 \\
\hline Филифолид А & 17,66 & 4,05 & 1328 \\
\hline (Z)-Жасмон & 20,25 & 0,81 & 1403 \\
\hline Итого & & 90,88 & \\
\hline
\end{tabular}


Таблица 2. Летучие соединения бензольного экстракта надземной части A. serotina

\begin{tabular}{|c|c|c|c|}
\hline Название вещества & $\mathrm{R}_{\mathrm{t}}$, мин & Содержание, \% & RI \\
\hline$\alpha$-Пинен & 5,53 & 0,26 & 935 \\
\hline 5,5-Диметил-2(5Н)-фуранон & 6,04 & 1,31 & 955 \\
\hline$n$-Кумол & 8,02 & 2,42 & 1027 \\
\hline Эвкалиптол (1,8-цинеол) & 8,19 & 10,08 & 1033 \\
\hline$\gamma$-Винил- $\gamma$-валеролактон & 8,51 & 1,24 & 1043 \\
\hline $\alpha$-Изофорон & 11,05 & 1,80 & 1124 \\
\hline Хризантенон (2-пинен-7-он) & 11,19 & 13,00 & 1128 \\
\hline 4-Оксоизофорон & 11,81 & 1,32 & 1147 \\
\hline Пинокарвон & 12,43 & сл & 1166 \\
\hline 4-Терпинеол & 12,94 & сл & 1181 \\
\hline$n$-Цимол-8-ол & 13,26 & сл & 1191 \\
\hline Вербенон & 14,00 & 0,33 & 1213 \\
\hline Не идентифицировано & 14,14 & 0,59 & 1217 \\
\hline Нордаванон & 14,70 & 0,92 & 1234 \\
\hline Аскаридол & 14,97 & 6,96 & 1242 \\
\hline Не идентифицировано & 15,53 & 0,39 & 1259 \\
\hline 3-Метил-6-(1-метилэтил)-7-оксабицикло[4.1.0]гептан-2-он & 15,61 & 0,85 & 1262 \\
\hline Не идентифицировано & 16,73 & 0,90 & 1295 \\
\hline 3-Метил-6-(1-метилэтил)-ацетат 2-циклогексен-1-ола & 17,03 & 1,12 & 1304 \\
\hline Изоаскаридол & 17,21 & 0,58 & 1310 \\
\hline Филифолид А & 17,67 & 8,62 & 1324 \\
\hline Не идентифицировано & 19,10 & 0,43 & 1367 \\
\hline 3-(5-Метил-5-винилтетрагидрофуран-2-ил)буган-2-ол & 19,59 & 5,50 & 1382 \\
\hline (Z)-Жасмон & 20,25 & 1,95 & 1402 \\
\hline Эспатуленол (Espatulenol) & 25,74 & 0,49 & 1575 \\
\hline Даванон & 26,05 & 1,11 & 1585 \\
\hline Метил жасмонат & 27,92 & 1,23 & 1645 \\
\hline Не идентифицировано & 30,63 & 17,98 & 1731 \\
\hline Итого & & 81,38 & \\
\hline
\end{tabular}

Основными компонентами $A$. sogdiana являются 5,5-диметил-2(5Н)-фуранон - 17,99\%, $\gamma$-винил- $\gamma$ валеролактон - 8,71\%; монотерпеноиды: 1,8-цинеол - 28,13\%, $\alpha$-туйон $-3,18 \%$, $\beta$-туйон - 2,69\%, камфора - 8,65\%, филифолид А - 4,05\%, хризантенон - 5,23\%.

Все представленные в таблице 1 соединения в надземной части A. sogdiana идентифицированы впервые. Основными компонентами A. serotina являются 1,8-цинеол - 10,08\%, филифолид А - 8,62\%, хризантенон - 13,00\%, (Z)-жасмон - 1,95\%.

Bce представленные в таблице 2 соединения Artemisia serotina, произрастающей в Узбекистане, (кроме 1,8-цинеола) идентифицированы впервые.

Известно, что почти все полыни содержат в своем составе 1,8-цинеол, камфору, $\alpha$-пинен, хризантенон [6]. По-видимому, эти летучие соединения являются маркерами для эфирных масел полыней.

Представленные в данном сообщении A. sogdiana и A. serotina имеют в наличии $\alpha$-пинен, 5,5-диметил-2(5Н)-фуранон, $\gamma$-винил- $\gamma$-валеролактон, 1,8 -цинеол, хризантенон, $\alpha$-изофорон и филифолид А, которые могут стать маркерными соединениями для них.

В заключение необходимо отметить, что обнаруженные летучие монотерпеноиды $\alpha$ - и $\beta$-туйоны, камфора и 1,8-цинеол являются активными ингибиторами прорастания семян и роста проростков окружающих однолетних растений, а также то, что продуцируемые растениями летучие органические соединения являются важным фактором для межвидового взаимодействия организмов в экосистемах [7].

\section{Выводы}

В результате проведенных исследований методом хромато-масс-спектрального анализа бензольных экстрактов надземных частей $A$. sogdiana и A. serotina впервые идентифицировано 19 и 22 соединения соответственно.

\section{Список литературы}

1. Шамьянов И.Д., Закиров С.Х., Абзалов А.А. Эколого-биохимические и прикладные аспекты полыней Узбекистана // Кимёнинг долзарб муаммолари : тезисы Республиканской научной конференции. Самарканд, 2009. Ч. II. C. 66. 
2. Kapustina L.A., Torrell M., Vallès J. Artemisia Communities in Arid Zones of Uzbekistan (Central Asia) // USDA Forest Service Proceedings RMRS-P-21. 2001. Pp. 104-112.

3. Определитель Средней Азии. Критический конспект флоры / под ред. А.И. Введенского, Р.В. Камелина. Ташкент, 1993. Т. 10. С. 581.

4. Горяев М.И., Сатдарова Э.И. Исследование эфирного масла Artemisia serotina Bge. // Труды института химических наук АН КазССР. 1959. Т. 4. С. 37-43.

5. Растительные ресурсы СССР. Цветковые растения, их химический состав, использование / отв. ред. П.Д. Соколов. СПб., 1993. Т. 7. С. 63.

6. Атажанова Г.А. Терпеноиды эфирных масел и экстрактов полыни : автореф. дисс. ... канд. хим. наук. Караганда, 1999. 22 с.

7. Харборн Дж. Введение в экологическую биохимию. М., 1985. С. 246.

Поступило в редакицию 21 ноября 2016 г.

После переработки 22 декабря 2016 г.

Mukhamatkhanova R.F.*, Bobakulov Kh.M., Shamyanov I.D., Abdullaev N.D. TERPENOIDS AND OTHER COMPONENTS OF ARTEMISIA SOGDIANA AND A. SEROTINA, GROWING IN UZBEKISTAN

Acad. S.Yu.Yunusov Institute of the Chemistry of Plant Substances Uzbek Academy of Sciences, ul. Mirzo Ulugbeka, 77, Tashkent, 100170 (Uzbekistan),e-mail:rfm8@yandex.ru

It was conducted the investigation of secondary metabolites by gas chromatography-mass spectral analysis of benzene extracts of the aerial parts of Artemisia sogdiana Bunge. and Artemisia serotina Bunge., collected during budding and early flowering spurs Nurata ridge Jizzakh region of Uzbekistan.

The basic components of $A$. sogdiana are 5,5-dimethyl-2(5H)-furanone - 17,99\%, $\gamma$-vinyl- $\gamma$-valerolactone $-8,71 \%$; monoterpenoids: 1,8 -cineole $-28,13 \%$, $\alpha$-thujone $-3,18 \%, \beta$ - thujone $-2,69 \%$, camphor $-8,65 \%$, filifolide $\mathrm{A}-4,05 \%$, chrysanthenone $-5,23 \%$.

The basic components of A. serotina are 1,8-cineole - 10,08\%, filifolide A - 8,62\%, chrysanthenone - 13,00\%, (Z)-jasmone - 1,95\%.

The represented in this report $A$. sogdiana and A. serotina both have available $\alpha$-pinene, 5,5-dimethyl-2(5H)-furanone, $\gamma$-vinyl- $\gamma$-valerolactone, 1,8 -cineole, chrysanthenone, $\alpha$-isophorone and filifolide A, which could be marker compounds for them.

It should also be noted that the detected volatile monoterpenoids $\alpha$ - and $\beta$-thujones, camphor and 1,8-cineole are active inhibitors of seed germination and growth of seedlings of annual plants surrounding.

The analysis identified 19 and 22 compounds of those Artemisia species for the first time, respectively.

Keywords: Artemisia sogdiana Bunge., Artemisia serotina Bunge., terpenoids, secondary metabolites, gas chromatography-mass spectral analysis.

References

1. Sham'ianov I.D., Zakirov S.Kh., Abzalov A.A. «Kimening dolzarb muammolari»-tezisy Respublikanskoi nauchnoi konferentsii. ["Kimyoning dolzarb muammolari" - theses of the Republican scientific conference]. Samarkand, 2009, vol. II, p. 66. (in Russ.).

2. Kapustina L.A., Torrell M., Vallès J. USDA Forest Service Proceedings RMRS-P-21., 2001, pp. 104-112.

3. Opredelitel' Srednei Azii. Kriticheskii konspekt flory [The determinant of Central Asia. Critical summary of flora], ed. A.I. Vvedenskiy, R.V. Kamelin. Tashkent, 1993, vol. 10, p. 581. (in Russ.).

4. Goriaev M.I., Satdarova E.I. Trudy instituta khimicheskikh nauk AN KazSSR, 1959, vol. 4, pp. 37-43. (in Russ.).

5. Rastitel'nye resursy SSSR. Tsvetkovye rasteniia, ikh khimicheskii sostav, ispol'zovanie [Plant resources of the USSR. Flowering plants, their chemical composition, use], ed. P.D. Sokolov. St. Petersburg, 1993, vol. 7, p. 63. (in Russ.).

6. Atazhanova G.A. Terpenoidy efirnykh masel i ekstraktov polyni. Avtoref. diss. ... kand. khim. nauk. [Terpenoids of essential oils and wormwood extracts. Author's abstract. Diss. ... cand. Chem. Sciences]. Karaganda, 1999, 22 p. (in Russ.).

7. Dzh. Kharborn. Vvedenie v ekologicheskuiu biokhimiiu [Introduction to environmental biochemistry]. Moskva, 1985, p. 246. (in Russ.).

\footnotetext{
* Corresponding author.
} 